\title{
THOUGHTS ON THE ARBITRATION OF PRICE REDETERMINATION UNDER GAS PURCHASE CONTRACTS IN ALBERTA
}

\author{
G. A. HOLLAND*
}

\begin{abstract}
This article discusses the use of arbitration in Alberta in relation to the problems of price redetermination under gas purchase contracts. Various price redetermination clauses allowing arbitration are discussed in detail, and the rationale behind such clauses is analyzed. The author then discusses the method of appointment of arbitrators, and in particular, the dangers and effects of appointing a "biased" arbitrator. In order for arbitration to work quickly and effectively, the author suggests that a pre-arbitration agreement is a necessity and he outlines certain essential conditions which should be determined before a dispute proceeds to arbitration. The "commodity value concept" and its role in determination of prices in gas purchase contracts is examined, followed by a review of recent Western Canada arbitration awards. Finally, the author summarizes the involvement of the Alberta Gov. ernment in the matter of price redetermination, and in particular, examines the question of whether or not the proposed amendments to The Arbitration Act are constitutionally valid.
\end{abstract}

\section{TYPICAL CONTRACT PROVISIONS}

\section{Arbitration Clause}

The typical arbitration clause contained in the gas purchase contracts of TransCanada Pipe Lines provides that either party may serve a written demand on the other party and within ten days of the service of that demand both parties are to name their respective arbitrators. The two arbitrators thus appointed agree upon and appoint a third arbitrator. If agreement cannot be reached as to the third arbitrator, then either party may apply to the Trial Division of the Supreme Court of Alberta for appointment of the third arbitrator. The decision of the arbitrators is to be given in writing and is to be made within 45 days after the appointment of the third arbitrator.

\section{Price Redetermination Clause}

The price clauses of the TransCanada gas purchase contracts all provide that if the parties are not able to mutually agree on the price when the question of price redetermination arises, then the matter is to be referred to arbitration. However, while all the contracts cause the matter to be referred to arbitration, the gas purchase contracts utilized by TransCanada over the past 15 years vary somewhat in the description of how that price is to be redetermined by the arbitrators.

The earliest form of contract used by TransCanada (Type A) provides as follows:

In any redetermination of the price of the natural gas to be purchased hereunder, the price fixed shall be such that it will permit, upon the assumption (except to the extent that is clearly not the fact) that the price of all other natural gas purchased by the Company is correspondingly increased, the Company to earn annually a rate of return on its rate base (including a reasonable allowance for working capital), after payment of all operating expenses including all taxes and provisions for depreciation and depletion, which will be adequate to permit the Company to earn a reasonable rate of return and to finance the expansion of its pipe line system, in accordance with the general rate making principles established by the Board of Public Utility Commissioners of the Province of Alberta in its decision, dated July 26, 1951, in the matter 
of an application by Northwestern Utilities Limited for variation of its rates. Notwithstanding anything contained in this contract to the contrary, it is understood that Buyer does not necessarily agree hereby that a rate of return on its rate base equal to seven-and-one-half per cent $(7 \cdot 1 / 2 \%)$ is a fair and reasonable rate of return based upon the existing conditions in the present money market.

A side letter agreement sent out by TransCanada with the original Type A contracts explained that the monies "to finance the expansion" were included in and not in addition to the "reasonable rate of return" referred to in the price redetermination clause.

The second form of price clause most commonly used by TransCanada (Type B) provides as follows:

In determining such prices and the effective dates thereof, the parties hereto or the arbitrator or arbitrators, as the case may be, shall have regard to any and all matters which either or both of the parties hereto consider to be relevant in connection with the determination thereof.

TransCanada has to a limited extent also used a third type of contract (Type $\mathrm{C}$ ) in which the following provision occurs:

In arriving at prices and the effective dates thereof, whether by mutual agreement or by arbitration, the parties hereto or the arbitrator or arbitrators, as the case may be, shall have regard to all matters which either or both of the parties hereto consider to be relevant in connection with the determination thereof. Without restricting the right to have regard to other matters, regard shall be had, in any event,

(a) primarily to the prices which Buyer is obligated thereafter to pay under other gas purchase contracts made within the two year period prior to the date of redetermination for gas to be produced in the Province of Alberta, taking into consideration the relative conditions in connection with the purchase by Buyer and sale by the producers of such gas, particularly quality, quantity and location, as compared with the relative conditions in connection with the purchase by Buyer and sale by Seller of gas hereunder; and

(b) secondarily, to the determination of prices which, upon the assumption (except to the extent that it is clearly not the fact) that such prices shall become of general application to Buyer's purchases of gas after such redetermination, will not be inconsistent with the financial well-being of Buyer.

The Type A clause appears in the earliest contracts entered into by TransCanada in Alberta at which time the TransCanada project was being set up in the mid-1950's. It was principally Canadian Gulf Oil Company and Hudson's Bay Oil and Gas Company Limited that negotiated the first contracts with TransCanada during the period from 1954 to 1956 . Looking back at the files relating to those early contract negotiations two matters stand out:

(a) the price redetermination clause was placed in the gas purchase contracts at the insistence of the producers and

(b) no comparable provision was to be found in the gas pruchase contracts then being used in the United States.

The gas purchase contracts being used in the United States in the mid-1950's provided for price redetermination at fixed intervals but the typical United States clause provided only that the price was to be increased up to the average of the prices being paid by that buyer under the three highest priced contracts entered into by the buyer for gas produced from the same area. In Alberta we would consider this more as a "favoured nations" clause as it entitled the seller only to receive what the other producers were receiving and did not allow the producer a price redetermination based on changed commodity value for the natural gas.

TransCanada had apparently been prepared to include a favoured 
nations clause of some sort in the early contracts. However, it was Mr. Blackstock, who was General Counsel of Canadian Gulf Oil Company, who prepared the first draft of the price redetermination provision in 1954, which draft specifically referred to "the increased commodity value for gas". This clause went through several redrafts until the first contracts for Pincher Creek and Nevis Fields were signed in February 1956. These early contracts were replaced a year later by contracts dated January 1957.

The favoured nations concept of the United States contracts probably gave rise to the so-called "ratchet provision" under the Type A contracts. The ratchet provision which forms part of the price clause sets out that the seller will not receive less than the weighted average of the price paid by TransCanada for all gas purchased by TransCanada in Alberta. The favoured nations idea probably also gave rise to paragraph (a) in the portion of the Type $C$ price redetermination clause quoted above.

The basic reason for the producers insisting on a price redetermination clause was, of course, the fact that the initial prices to be paid under the TransCanada gas purchase contracts were extruordinarily low. This low price was forced on the producers because of the relatively low commodity value of natural gas at that time when there was no substantial market yet established for natural gas and also by the very real uncertainty as to the economic feasibility of the entire TransCanada project. This uncertainty as to the economic feasibility of TransCanada arose because of the Federal Government's insistence on an allCanadian route for the project and its refusal to allow, at that time, export of gas to the United States. The volume of gas originally exported by TransCanada to the United States was simply a swap-out arrangement for like volumes of gas being imported into Eastern Canada in order to assist in getting the Eastern Canadian gas market established. Because of the economic uncertainty of the TransCanada project it was the Western Canadian producer who was forced to take a very low price while the Eastern Canadian manufacturers flourished. Because it was fully anticipated that there would be a substantial increase in the commodity value of natural gas over the life of the contract, it was essential that the producers have in the contract a price redetermination provision allowing a new price to be fixed based on a changed commodity value. Additionally, today we see TransCanada as an economically sound project with a guaranteed nine per cent annual rate of return.

\section{Effective Date of Price Increase}

A clause granting a price redetermination on a particular date is a somewhat illusory right unless the contract between the parties goes further and states that the particular date of price redetermination is also the effective date of the price increase irrespective of when the parties decide on the new price or the date of the arbitration. There are many contracts between TransCanada and producers in Alberta that provide for price redetermination on January 1,1973 , but as of the writing of this paper, TransCanada had not either by agreement or by arbitration redetermined the prices under any of those contracts.

Two British Columbia arbitration awards and the one Alberta award that have been made to date have all provided that the effective date of the price increase is the date of the decision of the arbitrators. However, in the Alberta arbitration of Westcoast Transmission and Petrogas 
Processing Ltd. an additional three-quarters of a cent was added to the revised price as compensation for the period prior to the date of the arbitration decision. In the British Columbia arbitrations no such compensation was given, notwithstanding the authority of the arbitration board to grant a price adjustment that would have compensated the producer for the loss of income between the date on which the price was to be redetermined and the date on which the arbitration award was made.

It is submitted that any agreement which provides for price redetermination on a particular date should also state that the price increase is to be effective as of that same date, otherwise the date of the price redetermination is an illusory right and largely unenforceable.

\section{APPOINTMENT OF ARBITRATORS}

The selection of an arbitrator to act on behalf of the producer requires a careful consideration as to the type of person best suited for the job. Firstly, all of the arbitrators are in theory "impartial", notwithstanding that at the arbitration hearing and in the making of the decision by the arbitration board the arbitrator appointed by a party will be a strong advocate for the position of the party which that arbitrator represents.

The question of the appointment of prejudiced arbitrators was considered by the Supreme Court of Canada in the case of Szilard v. Szasz.' Rand J., who gave the judgment of the Court, reviewed the various cases on the subject and his judgment can be considered as a complete statement of the law in Canada on this question and the case is undoubtedly the leading Canadian case on the subject. In this case the respondent, Szasz, had appointed as his arbitrator one Sommer who owned certain land jointly with the respondent. The following portions of the judgment are relevant: ${ }^{2}$

From its inception, arbitration has been held to be of the nature of judicial determination and to entail incidents appropriate to that fact. The arbitrators are to exercise their function not as the advocates of the parties nominating them, and $a$ fortiori of one party when they are agreed upon by all, but with as free, independent and impartial minds as the circumstances permit. In particular, they must be untrammelled by such influences as to a fair-minded person would raise a reasonable doubt of that impersonal attitude which each party is entitled to. This principle has found expression in innumerable cases, and a reference to a few of them seems desirable.

In Kemp v. Rose $^{3}$ the Vice-Chancellor remarked:

"A perfectly even and unbiased mind is essential to the validity of every judicial proceeding.

Therefore, where it turns out that, unknown to one or both of the persons who submit to be bound by the decision of another, there was some circumstance in the situation of him to whom the decision was intrusted which tended to produce a bias in his mind, the existence of that circumstance will justify the interference of this court....

In Conmee v. Canadian Pacific Railway Companyt the fact that pending the reference and before the finding, one of the arbitrators had received an intimation that the solicitorship of the defendant's company would be offered him and after the finding the offer was made and accepted, was likewise, held fatal. The authorities were thoroughly reviewed by Rose J. and at page 654 he quotes from Redman's Law of Awards:

\footnotetext{
[ [1955] S.C.R. 3.

2 Id. at 4 et. seq.

365 E.R. 910.

+ (1888) 16 O.R. 639.
} 
'It cannot be too strongly impressed upon arbitrators that the first great requisite in persons occupying that post is judicial impartiality and freedom from bias ....

These authorities illustrate the nature and degree of business and personal relationships which raise such a doubt of impartiality as enables a party to an arbitration to challenge the tribunal set up. It is the probability or the reasoned suspicion of biased appraisal and judgment, unintended though it may be, that defeats the adjudication at its threshold. Each party, acting reasonably, is entitled to a sustained confidence in the independence of mind of those who are to sit in judgment on him and his affairs ....

It is likewise impossible to place on Szilard the responsibility for the non-disclosure. He had been assured in effect that Sommer was free from factors that might influence his judgment or cause Szilard to reject him, and it would be asking too much to require him to catechize either Szasz or Sommer in order to verify that assurance. The details of the relationship should have been volunteered by Szasz.

What this case means in practice is that the producer and the pipeline company must both select arbitrators who have not acted as counsel for them in the past and who have no interest, financial or otherwise, in the party which they represent. All of this notwithstanding that the arbitrator will be paid (and well paid) by the party that he is representing.

This appears to require, for example, that if one of the parties appoints as its arbitrator an economic consultant, then that party cannot hire that same economic consultant to carry out research relating to the arbitration. Notwithstanding the legal impartiality of the arbitrator, one of the primary characteristics that a good arbitrator should have is that of being an effective advocate. The producer and the pipeline company will, of course, each be represented at the arbitration hearing by its own counsel, but sitting right beside the third arbitrator will be the arbitrator appointed by the respective parties. These arbitrators in practice will be a persuader on behalf of the producer and the pipeline company respectively. The problem here is the discrepancy between the legal theory of impartiality and the real world of an arbitration hearing.

But what the legal theory does mean is that neither of the arbitrators can be briefed ahead of time by the party he represents in the absence of the other arbitrators. If the producer or the pipeline company should carry out such a briefing, it does so at its own peril.

Once the producer and the pipeline company have each designated their respective arbitrator, then, theoretically, the two arbitrators thus appointed select a third man. In practice, the two parties to the arbitration will have a decisive say as to who is to be the third man. Indeed, the parties may directly carry out the negotiations leading to the appointment of the third man.

A transmission company will not want a man from the oil and gas industry and the producer will not want a man who has been closely identified with the interest of eastern consumers. The result will probably be the appointment of a man from a non-related industry or from non-related employment.

\section{PRE-ARBITRATION AGREEMENT}

As the parties move towards the arbitration hearing it will be useful to enter into an agreement to cover the following matters:

(1) To confirm that all the proper notices have been given to trigger the arbitration as this will avoid the need of formally proving the giving of proper notice at the hearing;

(2) To confirm the appointment of the respective arbitrators by the 
producer and the pipeline company and also to confirm that the two arbitrators thus appointed have appointed the third man;

(3) Depending on the state of the proceedings it may be desirable for the agreement to fix the date for the arbitration proceedings to commence;

(4) The gas purchase contracts generally provide that the decision of the arbitrators is to made within 45 days of the appointment of the third arbitrator. It may well be necessary to agree to some extension of this time period;

(5) The agreement will identify the gas purchase contract or contracts that are to be the subject of the arbitration proceeding;

(6) If several contracts are involved, then provision should be made for the arbitrators to make a separate award for each contract but this should not require the arbitrators to give necessarily a separate decision for each contract;

(7) If the parties have already agreed as to the effective date of the price increase, then that date should be set out for the benefit of the arbitrators.

Various other matters could be included depending on the circumstances of the case, including, for example, the payment of the fees and expenses of the arbitration and that the scale of fees set out in The Arbitration Act of Alberta is not applicable.

\section{COMMODITY VALUE CONCEPT}

A possible definition of "commodity value" would be:

'Commodity value of natural gas' means the overall or weighted average market value of competitive alternative energy sources in the regional market areas in which the natural gas is being or is to be consumed, as obtained by weighting the volumes and prices of the said alternative energy sources in each of the said market areas having regard to the mix of end uses and the volume of natural gas consumed or to be consumed by end use in each of the said market areas, plus any value that may be attributable to natural gas as a premium form of energy as a result of consumer preference for or the necessity to use natural gas as compared to alternative energy sources.

It would follow from this definition that the "field value of natural gas" could be defined as follows:

'Field value of natural gas' under any gas purchase contract means the commodity value for natural gas less all just or fair and reasonable costs, charges and deductions that are or may be fixed, determined or allowed for the transportation and distribution of that natural gas from the point of sale under that gas purchase contract to the point of delivery to the ultimate consumer.

Using the definition of "commodity value" in the case of an Alberta and Southern gas purchase contract, for example, is not unduly complex because the gas purchased by Alberta and Southern is marketed entirely in the California market area. The alternative energy sources in California can be identified quite easily and weight given to their proportions of the market. The single most significant alternative energy source is No. 2 fuel oil but other alternative sources are No. 6 fuel oil, bunker fuel, propane, electrical energy and coal. The volume and price 
of each of these alternative energy sources can be determined and the commodity value fixed for natural gas. The value to be added to the price of natural gas (as part of the commodity value) as a premium form of energy may be quite high in California because of the clean-burning characteristics of natural gas and the advanced pollution problems of California.

The commodity value of the natural gas sold under the TransCanada gas purchase contracts is more complex to determine because of the several markets served by TransCanada. In addition to the large Southern Ontario market, TransCanada gas is marketed in Saskatchewan, Manitoba, Northern Ontario, Montreal and the Northern United States. Each of these market areas has its own commodity value for natural gas. Each area must be analyzed, the proportion of the total TransCanada gas sales to each market area determined and a weighted average calculated. This is not to say that the commodity value for TransCanada cannot be determined with considerable accuracy but the research and analysis required is much greater than is the case for determining the commodity value for gas under the Alberta and Southern contracts. The commodity value approach was expressed very well in the arbitration proceeding between Westcoast Transmission and Imperial Oil. At 1503 of the transcript, D. M. M. Goldie, Q.C., appearing for Imperial Oil, quoted from the submission of Westcoast Transmission to the Royal Commission on Energy (the Borden Commission) in 1958. In the Westcoast submission it is stated that: ${ }^{5}$

In general, there is no reason why the price of gas in the field will not be fixed by the same economic principles applicable to other mineral products, namely the competitive value of the product at the point of consumption, less the cost of transportation.

There can be no doubt that commodity value was, in fact, the basis on which the prices under the gas purchase contracts were originally agreed upon. In the meantime, however, the transmission companies have had a bad case of selective amnesia and now claim never to have heard of commodity value.

\section{ARBITRATION AWARDS IN WESTERN CANADA}

To date there have been the following arbitration decisions relating to the redetermination of price under gas purchase contracts:

(a) In the arbitration between Westcoast Transmission Company Limited and Petrogas Processing Ltd. relating to gas produced in Alberta, the majority of the arbitration board in its decision dated December 20, 1971 granted Petrogas a price increase of from 3.5 cents per Mcf in 1972 to 5.5 cents per Mcf in 1975. There was added to this price increase throughout an additional $3 / 4$ cent per Mcf "being an amount estimated to provide for increased price that the majority of the arbitrators considered appropriate for the year 1971." The date of the price redetermination under the contract was January 1, 1971.

The majority award gave no reasons for the decision but from the size of the award it is clear that the majority (the Chairman and the Westcoast appointed arbitrator) rejected the commodity value approach to the pricing of natural gas and also proceeded on

s Royal Commission on Energy, First Report (1959) at $6 \overline{5}$. 
the mistaken belief that a greater increase in price would unduly affect the financial well-being of Westcoast Transmission, when in reality Westcoast Transmission is entitled to pass on any increase in price to its customer, El Paso.

(b) In the arbitration between Westcoast Transmission and Petrofina Canada Ltd., relating to gas produced in British Columbia, the majority of the board (the Chairman and the Westcoast appointed arbitrator) in its decision dated December 19, 1972 granted Fina a price increase of 3 cents per Mcf effective January 1, 1973. No increase was granted for 1971 or 1972 , notwithstanding that the date for price redetermination was January 1, 1971. No reasons were given for the majority award but, because of the incredibly small increase, it is safe to assume that the majority rejected the commodity value approach in the pricing of natural gas and presumably rejected every other submission made on behalf of Fina.

(c) The arbitration decision between Westcoast Transmission and Imperial Oil Limited dated February 15, 1973 also related to British Columbia gas. In this case the majority of the arbitration board (the Chairman and the arbitrator appointed by Imperial) granted a price increase of 8 cents per Mcf effective March 1, 1973. Again no price increase was made for the years 1971 or 1972, notwithstanding that the date of price redetermination was January 1,1971 . However, the increase in price was a substantial improvement over previous decisions. The decision meant that the base price to be paid under the contract was to be 21 cents per Mcf. It should be remembered that this price is for raw, unprocessed gas. The cost of processing natural gas is generally estimated to be between 5 and 6 cents per Mcf. Accordingly, this award is equivalent to a price of 26 to 27 cents for processed gas. While the majority did not give reasons for the award, the decision appears to indicate the general acceptance of the commodity value approach. However, the concern of the Chairman for the financial well-being of Westcoast would appear to have limited the extent that he was prepared to implement the commodity value price and also to account for the lack of any increase for the years 1971 and 1972.

\section{INVOLVEMENT OF THE GOVERNMENT OF ALBERTA}

Over the past year the Government of Alberta has become deeply involved in the matter of gas price redetermination with TransCanada PipeLines Limited in order to achieve better prices for the natural gas produced in Alberta. Some of the moves made by the Government of Alberta are as follows:

(1) In July, 1972 the Government initiated an enquiry by the Energy Resources Conservation Board as to the field price of natural gas. The report of that Board published in late August 1972 concluded that the field price of gas in Alberta should be based on commodity value.

(2) On November 16, 1972 the Government of Alberta issued a statement in which, among other things, the Government adopted the recommendations of the Energy Resources Conservation Board 
that the commodity value should be the basis for natural gas prices in Alberta.

(3) On January 29, 1973 the Minister of Mines and Minerals for Alberta announced that the Government would, at the current session of the Legislature, bring forward amendments to The Arbitration Act of Alberta that would provide:

(i) that the arbitrators shall use the commodity value of natural gas as the price criterion in redetermining price under gas purchase contracts;

(ii) the arbitrators shall be Albertans; and

(iii) the arbitrators would be authorized to set the effective date for the redetermined price (presumably authorizing a retroactive increase).

(4) In March 1973 the Government of Alberta formally announced that the Government would not issue any further permits for export of natural gas from Alberta until the price being paid under gas purchase contracts for gas produced in Alberta had been increased to its proper value.

(5) On April 10, 1973 the Minister of Mines and Minerals announced that the Energy Resources Conservation Board would be requested to review the permits issued to Consolidated Natural for the export of gas from Alberta to determine whether or not the operations under the permits are the same as the operations contemplated when the permits were issued. Consolidated Natural was refused an export license by the National Energy Board; and the volumes of natural gas that Consolidated Natural had contracted to purchase are presently being utilized by TransCanada. The hearing that commenced on July 10,1973 has been adjourned to allow for the presentation of argument as to the jurisdiction of the Energy Resources Conservation Board to review the permit.

The proposed amendments to The Arbitration Act are of interest from a constitutional point of view although the proposed amendments have not yet been enacted by the Alberta Legislature. The case of Carnation Company Ltd. v. Quebec Agriculture Marketing Board B $^{6}$ is interest with regard to the constitutional validity of the proposed amendments.

The facts of the Carnation Company case were that the Quebec Agriculture Marketing Board was created by the Government of Quebec and was empowered to approve joint marketing plans. In 1957 the Board approved a joint marketing plan for the Carnation Company and the producers who supplied milk to that Company. The plan was administered by a "producers' board" which had the power to negotiate with Carnation for the sale to it of the milk produced by the producers under the plan. The parties were not able to agree as to the purchase price of the milk. The Quebec Agriculture Marketing Board, as it was authorized by law to do, intervened as arbitrator and determined the price which Carnation had to pay to its producers. Carnation purchased raw milk from approximately two thousand producers in the area of Sherbrooke, Quebec. At the Sherbrooke plant Carnation processed raw milk into evaporated milk. The major part of such production was shipped and sold outside of Quebec.

ธ [1968] S.C.R. 238. 
Carnation took the position that the orders of the Quebec Agriculture Marketing Board approving the plan and fixing the price were invalid because the orders enabled the Board to set a price to be paid by Carnation for a product the major portion of which was to be used for export out of Quebec and for this reason constituted the regulation of trade and commerce within the meaning of Section 91(2) of the B.N.A. Act, a field reserved to the Parliament of Canada.

The appeal to the Supreme Court of Canada was heard by a Court of seven justices; Martland J. delivered the unanimous decision of the Court. Martland J. reviewed in detail the judgments of the Farm Products Marketing Case ${ }^{7}$ and Lawson v. Interior Tree Fruit and Vegetable Committee of Direction 8 and concluded that the orders of the Quebec Agriculture Marketing Board did not infringe on the exclusive legislative power of the Parliament of Canada under Section 91(2) of the B.N.A. Act. Martland J. states: ${ }^{9}$

The purpose of the order was to to regulate on behalf of a particular group of Quebec producers their trade with [Carnation] for the sale to it, in Quebec, of their milk. Its object was to improve their bargaining position.

Martland J. subsequently stated that: ${ }^{10}$

The orders . . . were not ... directed at the regulation of interprovincial trade. They did not purport directly to control or to restrict such trade. There was no evidence that in fact the orders did control or restrict it. The most that can be said of them is that they had some effect upon the cost of doing business in Quebec of a company engaged in interprovincial trade and that by itself is not sufficient to make them invalid.

Given this judgment as the most recent statement by the Supreme Court of Canada as to the legislative authority of the Province, it would appear that the proposed amendments to The Arbitration Act of Alberta are within the legislative jurisdiction of the Province.

\footnotetext{
: [1957] S.C.R. 198.

- [1931] S.C.R. 357.

9 Carnation Company Ltd. v. Quebec Agriculture Marketing Board, supra, n. 6 at 252.

10 Id. at 254 .
} 